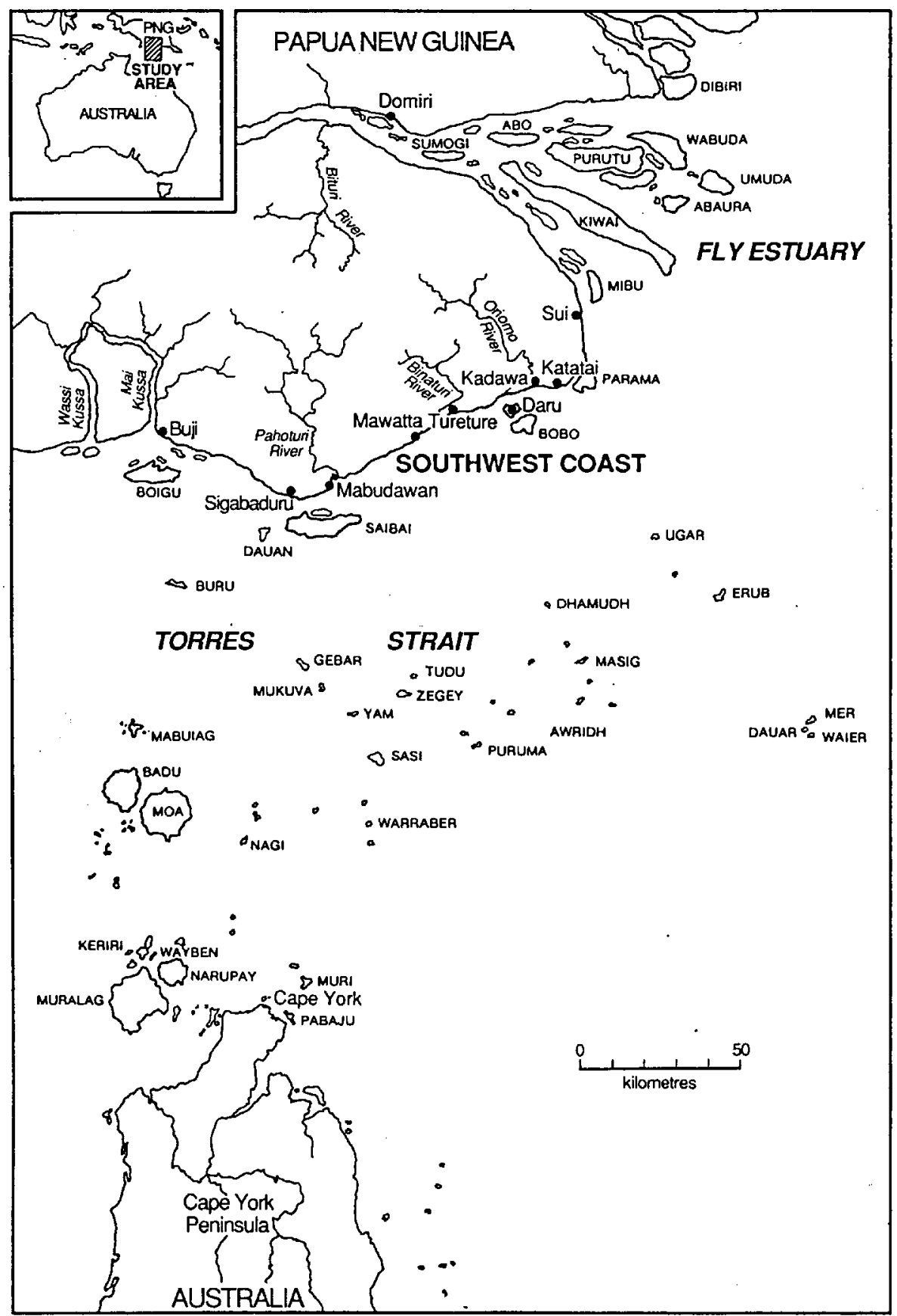

Torres Strait, Southwest coast and Fly Estuary Region. 


\title{
FROM THE OTHER SIDE
}

\author{
Recently collected oral evidence of contacts \\ between the Torres Strait Islanders and the Papuan peoples \\ of the southwestern coast
}

\section{David Lawrence}

Although the folk tales of the Papuan people of the southwestern coast of Papua New Guinea were first collected by Landtman ${ }^{1}$ and similar collections of tales were made in the Torres Strait by Haddon, ${ }^{2}$ Laade, ${ }^{3}$ Beckett ${ }^{4}$ and Lawrie, ${ }^{5}$ little attempt has been made to collect the oral evidence of the long and continuous history of contact between Islanders and Papuans who collectively share the Torres Strait region.

During fieldwork in 1985 in the Western Province of Papua New Guinea, as part of research on the material culture of the Torres Strait and Fly River estuary canoe trade, the author collected a number of oral accounts which specifically document this history of contacts in the daily life of the people of the southwestern coast of Papua New Guinea. The aim of this article is to present, with annotations, a number of these recently collected oral accounts from the Papua New Guinea side of Torres Strait.

All these stories collected in the field were recorded in the local language or dialect. The name of the storyteller, village language and dialect are noted at the beginning of each transcript. This recording was then replayed in full to the storyteller and, in some cases, additional material was added and changes made. Translations into English were made in the presence of the storyteller. The author wishes to thank Nano Moses and Robin Baiu for their assistance in translating from Kiwai and Bine languages. The following village elders are remembered with kindness for their courtesy and willingness to recall their oral history: Moses Somogi, Image Matai, Magermo Mereke, Side Saiade Ben, Kubu Ag, Zate Nog, Sair Buia, Jawagi Maru, Kanai Tura, Pomame Buji, Ibaji, Gadua, Abaim Mergor, Sarawa Jugu, Mundar Kaus, Sagare Kaus, Bisai Kaus and Birige Kugei.

The oral evidence presented in this article has been re-edited from the original field notes. It has been the author's intention to retain, as closely as possible, the original style and content of the story.

The research for this paper forms part of David Lawrence's PhD thesis dealing with the material culture of customary exchange in the Torres Strait and Fly Estuary region. At present he is librarian in charge at the Great Barrier Reef Marine Park Authority, Townsville.

\footnotetext{
1 Landtman 1917.

2 Haddon 1908, VI: 1904, V: 1935, I.

3 Laade 1971.

4 Beckett 1975.

5 Lawrie 1970.
} 


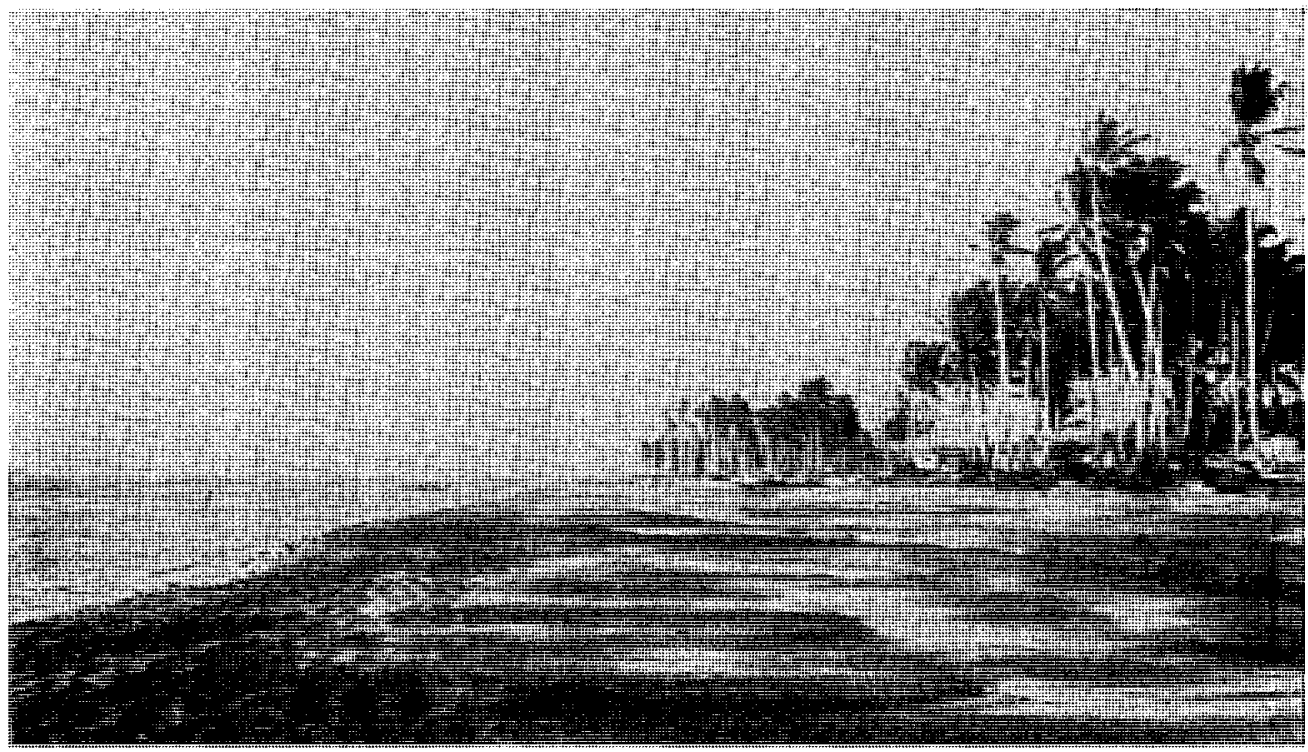

Above: Kadawa village, showing typical southwest coastal environment [photograph by David Lawrence, 1986]

Below: Men and women from Kadawa village (with author) preparing for long distance exchange voyage to the upper Fly estuary [photograph by Nano Moses, 1986]

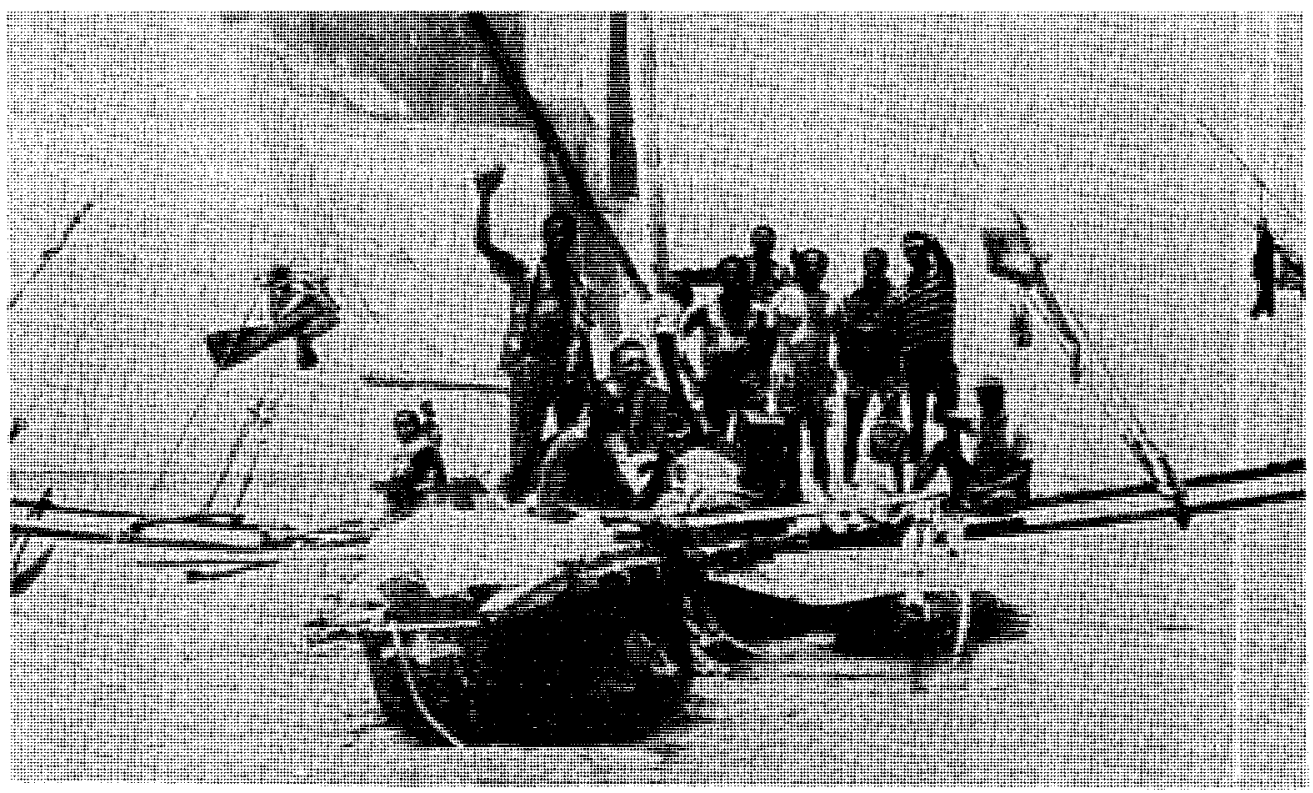




\section{FROM THE OTHER SIDE}

Contact with Europeans began in 1606, when Torres sailed through the Strait which now bears his name. Because more sustained contact commenced during the late eighteenth and the early nineteenth centuries, oral accounts of the impact of the European way of life are still a vital part of the oral history of the Torres Strait peoples. This article concludes with some recently told stories concerning the coming of the 'white man' and his impact on the patterns of inter-ethnic contacts.

\section{Torres Strait.}

The Torres Strait consists of a reef-strewn passage between Cape York and the southwestern coast of Papua New Guinea, west of the Fly River delta. A little over 150 kilometres wide it contains over 100 islands, islets, coral reefs and cays lying between longitudes $141^{\circ} 15^{\prime} \mathrm{E}$ and $144^{\circ} 20^{\prime} \mathrm{E}$, and latitudes $9^{\circ} 20^{\prime} \mathrm{S}$ and $10^{\circ} 45^{\prime} \mathrm{S}$.

Geographically, and to some extent ethnographically, the inhabited islands can be divided into four groups. The high western islands, particularly Badu, Moa, Muralug, Mabuiag, Waiben and Dauan, are the weathered granite peaks of a drowned mountain range which extended from Cape York Peninsula to the hill at Mabudawan on the Papua New Guinea coast.

The northem low islands of Saibai and Boigu were formed by effluvia of rivers in Papua New Guinea and the alluvial accumulation of organic, inter-tidal and mangrove sediments on top of reef limestones and clay.

The central islands, particularly Yam, Masig, Warraber and Puruma are generally low sandy cays formed on coral limestone. Basically they appear as typical coral islands surrounded by extensive fringing reefs containing much fish life. Yam Island is the easternmost island with geographical characteristics of the Western Group.

The eastern islands of Mer, Erub and Ugar are high volcanic formations with weathered, rich brownish soil and contain steep, well vegetated slopes and exposed rock. Although the islands show signs of deforestation and soil erosion, they are fertile and picturesque tropical islands.

The peoples of the southwestern coast of Papua New Guinea, which extends from the Fly River delta to the Mai Kussa River share with the Torres Strait Islanders the reefs and waters of the Strait.

In contrast to the other parts of Papua New Guinea, most of the Western Province is a vast lowland region with mountains only in the north and north-west. The largest river in Papua New Guinea, the Fly River, effectively divides the Province. South of the Fly River is the Oriomo Plateau, a generally featureless undulating ridge extending from the lower Fly River to Irian Jaya, bordered on the south by a narrow coastal plain, the most prominent feature of which is the hill at Mabudawan. This narrow plain, intersected by widely spaced slow moving muddy rivers is subject to seasonal flooding and the shallow coastal waters are muddy, with reefs, mudbanks and shifting sandbars.

Along this coastal plain, extending from Parama Island to the Mai Kussa River, are small villages of the Kiwai, Gidra, Bine, Gizra and Agob speaking peoples. They combine swidden horticulture with gathering bush foods, sago making, hunting and fishing. Dialects of the coastal Kiwai language are spoken in the villages of Mabudawan, Mawatta, Tureture, Parama, Katatai, Kadawa and Daru; Gidra is spoken at Dorogori; Bine at Masingara and Kunini; Gizra at Waidoro and Kulalai; and Agob at Buji, Ber and Sigabaduru. 
This paper does not seek to provide evidence of linguistic affiliations across the Torres Strait, for this has been the subject of other research, notably by Wurm, ${ }^{6}$ and Wurm and Hattori. ${ }^{7}$ Wurm has stated that the prehistory of linguistic influence across Torres Strait has not been fully explained, but suggested that a southward Papuan linguistic influence into the Torres Strait may have taken place between 2000 and 3000 years ago. Alternatively, this southward move may have been a more recent result of raiding by the Kiwai people of the Fly River and the Marind (Tugeri) people of the Morehead River which forced coastal peoples to seek refuge in the interior or on the islands of the Torres Strait. ${ }^{8}$

However it appears that an Australian linguistic influence spread northward and probably predated the southward Papuan linguistic influence. ${ }^{9}$ It is apparent that linguistic influences moved in both directions across Torres Strait. This theory does not conflict with oral accounts for, as this oral evidence indicates, the movement of people across the Torres Strait commenced with the journeys of the culture heroes and ancestors and continued with the travels of village leaders and the people themselves.

\section{Origin Myths.}

According to Haddon ${ }^{10}$ and Laade ${ }^{11}$ the original settlers on the Murray Islands were said to have been Pop and Kod, who came from the Fly River to Zaub (presently the central area of Mer village). Laade ${ }^{12}$ noted another story which stated that three women from a shipwrecked fishing party swam ashore at Erub (Darnley Island) and Mer (Murray Island). These women were later seen by men from New Guinea who settled with them on the islands where they were subsequently joined by other New Guineans.

According to Laade, ${ }^{13}$ Maida was the first Yam Islander. However, stories relating to contact between Tudu and Yam Islanders and the people inland of the Binaturi River (Bine speaking people) are known. Tudu and Gebar people are said to have been the ancestors of those people who moved to Yorke Island (Masig), Nagi Island and Warraber Island. ${ }^{14}$

Laade $^{15}$ also stated that the first settler on Saibai Island was Melawal who lived underground in a bailer shell. Two others, 'bushmen' from Papua New Guinea named Nima and Poipoi, came from the east to the area where Melawal and Budia (a man from the west who moved around in the shape of a willy-wagtail) were living. Originally Saibai contained two settlements. The site of the present day Saibai was the area of Melawal and Bugia's home. Ait, the eastern point of Saibai, was the home of the Ait people from Papua New Guinea, perhaps from Togo up the Pahoturi River which can be seen across the passage.

The principal origin myth of the Kiwai speaking people is the story of Sido. The journey of Sido from U'Uwo on Kiwai Island to Saibai as told to the author is long and

\footnotetext{
6 Wurm 1972: 1975.

7 Wurm and Hattori 1981.

8 Wurm 1972: 360-366.

9 Wurm 1975:361.

10 Haddon 1908, VI: 19.

11 Laade 1968:141-142.

12 Laade 1968:142.

13 Laade 1968:145.

14 -Laade 1968:149.

15 Laade 1968:142.
} 
complex. It concerns the creation of Sido at Dibiri, near the mouth of the Bamu River. Sido was expelled from Dibiri because of the power of his magic. He then journeyed to U'Uwo on Kiwai Island where he was reborn through the body of a woman joined at the waist to her sister. These women taught Sido the magic of food and hunting and in return he split them apart so that they could live in separate places.

During his journeys around Kiwai Island, he met an old man who showed Sido the magic of making drums and small canoes. From the sound made by his first drum Sido learnt the name of a woman who lived at Iasa on the western side of the island and, using a magic tree, Sido transported himself to Iasa. With this woman, Sagaru, Sido sailed around Kiwai Island using a canoe fitted with a pandanus mat sail. However, Sido and Sagaru quarrelled over Sido's sexual abilities and she fled from Sido to the mainland. So Sido followed her aided by his magic children, the birds.

Sido made canoes from various trees, such as nipa palm, but these were unsuccessful. Finally, he made a large canoe from a strong tree. This canoe was in the form of a partially hollowed out (not dugout) canoe, and in the canoe Sido made room for his food, bows, arrows and his bird children.

Sido sailed to Mibu, where he met Sagaru again. Again, she fled, and Sido eventually followed her along the coast to Mabudawan. At Mabudawan, Sido climbed the hill and when he jumped down, his feet made an imprint in the rocks which can still be seen.

From Mabudawan where he met Sagaru, Sido went to Boigu Island, but they were followed by a man named Meuri who desired Sagaru. On Boigu, Meuri and Sido fought and Meuri cut off Sido's head. Meuri gave Sagaru water in the decapitated head but she threw it away and the place where it fell was turned into a deep well, which still exists on Boigu.

Meuri caused Sagaru's accidental death, but the spirits of Sido and Sagaru returned to U'Uwo where Sido's grave can still be seen in a place that stays green and fresh during all seasons. Sagaru's grave is not known.

Early versions of the Sido myth were also collected by Landtman ${ }^{16}$ and Beardmore ${ }^{17}$. According to Laade ${ }^{18}$ and Haddon, ${ }^{19}$ Sida or Sido, a Kiwai culture hero, was credited with introducing certain plant-foods into the Torres Strait, and Laade stated Sido journeyed as far as the Murray Islands before returning to Kiwai Island. The story can be interpreted in another way. The movements of Sido reflect the movements of the Kiwai people themselves. Although Sido journeyed to Boigu, in this story, told by one of the leading men from Iasa village, no mention is made of contact with the Murray Islands. However, the importance to the Kiwai people of the Sido myth is that it links their movements from Kiwai Island along the southwestern coast of Papua. Mabudawan is the western-most Kiwai speaking village.

Beckett, ${ }^{20}$ discussing the Sido myth, stated that the saga incorporates elements common to most creation myths in Oceania. These elements include:

the primeval killing; reincarnation through rebirth and through the shedding of the old body, followed by the acquisition of a new one; death becomes

\footnotetext{
16 Landtman 1917:95.

17 Beardmore 1890:465-466.

18 Laade 1971:1-8.

19 Haddon 1904, V:28-38.

20 Beckett 1975:177-178.
} 
irreversible; the separation of ghosts and mortals; and the establishment of a ghostly world. 21

In Melanesia, oral traditions form a record of the patterns of journeys of people as both traders and migrants:

These traditions of migration are significant to people's heritage, for the knowledge transmitted through generations in legend, song chant and dance constitute their basic legal, political, social and economic charters. It is on this basis that the rights and obligations of lineages are defined within communities, and both access to and use of specific resources and territories are defended. 22

The legendary journeys of culture heroes, the movements of traders, and village migrations become intermeshed. The colonial era opened new opportunities for movement.

Lacey ${ }^{23}$ has shown that oral traditions support the claim that between the 1880 s and the 1930s the impact of pacification and the establishment of foreign enclaves on the coast after the 1870 s and 1880 s resulted in a complete alteration of customary village life in Melanesia. The spread of the European ways is profoundly reflected in oral accounts of cross cultural contacts and village movements.

\section{Oral Traditions of Pre-European Contacts.}

Laade $^{24}$ argued that a series of statements concerning contact between Islanders and Papuans could be made from oral tradition:

(1) The eastern island traditions tell of people coming from the Fly River. raiding.

(2) The Muralag and Daru tradition tells of the Hiamo people who fled from Kiwai

(3) The Yam-Tudu and Papuan tradition tells of contact with the Papuan people of the Binaturi River region.

The following stories will show that this argument is correct.

Contacts between the Fly River people and the Eastern Islanders was possibly established by accidental voyage. Stories such as the following are still told:

Kadawa Village

Kiwai Language

East Coastal Kiwai Dialect

Story of a small boy who was swept from Kiwai Island to Murray Island Told by Moses Somogi

While the small children were swimming in the river off Kiwai Island, they saw a big log and started jumping off it. When they saw the log drifting out from the village, they all jumped off but the smallest boy could not swim far and he just stayed sitting on the log.

The current took the log out from the village to the sea. Day and night he sat on the log until it came to Murray Island. When the log came there the boy stayed sitting on the log until one man and his wife, going out to their gardens, found him there. 


\section{FROM THE OTHER SIDE}

The man and his wife asked him what had happened, but he could not talk. He made signs to tell them what happened. The man and his wife took him to their gardens with them. Then they hid him in their house because they did not want him killed. Both of them went to the headman to tell him about the boy and ask that they could keep him as their son.

The headman told them to bring the boy to him. He said that they could keep him in memory of the Fly River. The boy grew up and they gave him a wife and he had children. On Murray Island his big family can still be found.

A similar story, told by the people of the village of Sui, serves to link the Ipisia people with the Murray Islanders. In this story the children are swept from Murray Island up into the Fly River delta.

Sui Village

Kiwai Language

Coastal Kiwai Dialect

Story of two children swept from Murray Island

Told by Image Matai

When two children on Murray Island were swimming one day they fell asleep on a log. When the water rose it took the log and the children away. When they woke up they saw that the village was far away and they could not swim back. They had nothing to eat but small fish which they caught and dried in the sun. The water took them all the way to Ipisia. Here, they jumped off the log and hid in the nipa palms. Other children were playing at throwing toy arrows and one of these arrows went into the nipa palm near the children. One small boy went into the palms and saw the children hiding but he did not tell his friends. Instead, he went and spoke to his father, the headman. In the night, the father and mother of this boy went to the palms and took the children to their house where they built a small shelter and hid them. In those days they were still fighting and strangers could be killed. The parents tricked the other village people by saying that the shelter was for the man because he had a boil on his side and rested there. This headman told the village people that he wanted them to return early from their gardens that day as he had something to tell them.

When they returned in the evening he and his wife had dressed in their fighting gear. They took the children and showed them to the people, telling them that if they wanted to kill the children they must fight them first. The village people all said not to kill the children and allowed the headman and his wife to keep them as their own. After one month - when they could speak Kiwai - they told their story.

The Ipisia people later took their canoes and took the children back to Murray Island. Some of the people stayed at Murray Island, and others returned to Ipisia.

It is well known that the strong winds, tides and currents in the Fly River delta can carry large logs and even canoes across the Torres Strait and, as Landtman ${ }^{25}$ stated, floating tree trunks suggested a means of river transport, and he illustrated this by recounting a Kubira 
village story of accidental voyaging. The story of how the original inhabitants of Daru, the Hiamo-Hiamo people, fled into Torres Strait and settled on Muralug was told by Landtman. ${ }^{26}$ Although Laade ${ }^{27}$ stated that the origins of the Hiamo-Hiamo were obscure the following story serves to illuminate their Torres Strait rather than Papuan origins.

Kadawa Village

\author{
Kiwai Language \\ East Coastal Kiwai Dialect \\ Story of Daru (Yaru) \\ Told by Moses Somogi
}

At first on Daru Island, there were no mangrove trees. It was only a sandbank. The first man to come to Daru from Torres Strait was Gaidiri from Yam Island. There were Hiamo-Hiamo people on Daru. The people at Daru the Hiamo-Hiamo - originally came from Yam Island. They were called Hiamo-Hiamo by the Kiwai speaking people. Gaidiri married a Hiamo-Hiamo woman, called Bobo. Kiwai Island people and people from Katatai went from the mainland planning to kill the Hiamo-Hiamo people. Gaidiri and Bobo had died by this time, but their son was Damabe. When the fighting started Damabe was making his dugong harpoon. As there were no trees, the HiamoHiamo could not hide and so they were killed. Damabe escaped by covering himself with a turtle shell. People jumped over the shell while he was hiding under it. When the fighting finished they searched the island for other people. They then returned to their cances, sounded the conch shell and returned to the mainland. Damabe came out from under the shell and swam to Goli (a river on Bobo Island) where he lit a fire. The Katatai people saw the smoke coming from the bush. The Katatai people came to Goli, but told Damabe not to be frightened as they only came to get him (not to kill him). When they took Damabe back to Katatai they told Bani (a Boigu man) that they would give Damabe Bani's sister Makere in marriage. Damabe had children. The first was Ausa, the second Daida. Ausa's son was Daida Ausa. This man still lives at Kadawa.

This story serves to link the people of Kadawa with the people of Yam Island in the Torres Strait, a link also noted by Beaver. ${ }^{28}$ Landtman ${ }^{29}$ also collected stories concerning cross cultural links between Yam Island people and Daru people although in Landtman's story concerning the flight of the Hiamo-Hiamo from Daru he stated that the final home of the Hiamo-Hiamo was Muralug (Prince of Wales Island) and not Yam. ${ }^{30}$

In pre-contact times, the peoples of the southwestem coast of Papua New Guinea were subjected to repeated intergroup warfare and head-hunting raids, and it is probable that the Torres Strait Islands were used as places of refuge from the coastal people.

The following Kiwai story relates how the Torres Strait Islands came to be inhabited by people fleeing the uncertainty of mainland life.

Laade 1968:145.

28 Beaver 1920:49-50. 
Daru Town

Iasa Comer Village
Kiwai Language

Island Kiwai Dialect

Story of the Torres Strait People

Told by Mageramo Mareke

The people of the Torres Strait and the coastal people all look like the same people. The islander people ran away from here and settled on Darnley, Murray, Yam, Badu, Coconut, Dauan, Boigu, Masig. They ran away from here. The people in the bush, when you hear them, their language sounds the same as the islanders. The people who were strongest fled to the Torres Strait islands. The weaker ones went into the bush. Some of the weaker ones sank into the water, the stronger ones made it to the shore. There are people at Kerema, also Goaribari, Kaima (Gaima) and Komite. They are the same people also. Those people living in the Torres Strait - they were from the bush. They separated and some went to the islands. That's how the story went in the olden days.

The Kiwai speaking people were not the only group to maintain cross cultural contacts for kinship relations between Yam Island people and the coastal people of Papua New Guinea established the primary basis for continuing cross cultural contact. The following story details contacts between the Bine speaking peoples of Masingara village and Yam Islanders. The Bine people inhabit lands along the Binaturi River, and the coast to Kura Creek. They are excellent horticulturists and provide the administrative centre at Daru with garden produce. They exchange, with the coastal Kiwai, produce for fish, turtle and dugong.

Masingara Village

Bine Language

Masingle Dialect

Story of the Masingle People

Told by Side Saiade Ben

In the beginning, when we were living together, war broke out and we scattered, and looked for places to settle the clan. Udidariem clan settled and named the places, Ugri and Bullawe, but from there water disturbed them and they moved. Tiburi, our grandfather, when they were about to leave, left a wife pregnant there. They built a house in a big tree. There were bamboos near that tree. He told her to stay there. 'If you give birth to a girl, name her Kie, if it is a boy, name him Omebwale. When he gets big send him to see us', he told her.

From there, they made bamboo rafts and they came to a creek they called Omebwale-Mope-Gome (which flows to the Binaturi River). As they came they named the places Ablepupu, Gurewal, Casanbale, Eagibade, Sair, Gulpupu, Tabern, Uliwainglesai, Kuremomo, Topitaromi, Dipemaura and Gaigome.

Near the creek junction called Wome, some rafts sank and these people drowned.

They continued past the creeks called Ugenarame and Trimaarame. From there they came to Iairue and settled there. Later they moved to Wobede, 
Merinea, Siturangu, Binaturi and Busepuli. When they went towards the coast from the river they came to the east to Bulagabe on the coast, to Jomigape, to Guriwale, and to Magibade and Casambade. They used the same names that they had used along the river. Magibade is where the present village of Tureture is situated on the beach.

Between the coast and the inside, the places are Tuageu, Masingle-Gabe and Gluiasamiware. They were moving, trying to find a place to settle. They had to move to Iairue again because at Jomigape the water was salty. At Iairue they made a raft and followed the river down to the sea.

They journeyed by raft to the reefs and islands. To Guriwal, Casambade, Magibade, Tudamomo, Tabeani, and Garubui (Moon Passage), also to Iame (Yam Island), and Tudomo (Tudu Island).

When they returned from Tudomo they left behind a woman with a pig. From Tudomo, they went to Iame and settled there, and named the places with names from the mainland. Sugisugi (water well), Apala, Bullawe (river name). The people settled there and those names are there.

The pregnant lady (Tiburi's wife) gave birth to a boy whom she called Omebwale. When he grew up his mother told him that his grandparents and father had gone out from here and he should go and try to find them. When he was small his mother had fed him a special kind of sour taro called oge which made him sleepy and he had a vision. In the vision the sea spirit woman told him that he should find a canoe called 'Tibai Gul', and go in search of his people. A pig tried to kill people near his home so he killed it and cut it up and divided it. He got into his canoe and set off down the river. When he reached the ocean, near the reef, he threw the pig's head into the sea and it turned into a dugong. He threw the pig's leg into the sea and it became a turtle, the skin on the side became a stingray.

The other parts of the pig changed into fish. The sea spirit woman had given him a harpoon, which he used to spear those animals. He arrived at Yam Island in the night, and took with him those animals which he had caught. Secretly, he went to the house of his father, and fell asleep between his father and his eldest brother. His father awoke in the middle of the night, and wondered who this young man was, so he woke his eldest son and asked him but he did not know. The young man smiled to himself then woke and said to his father:'I am the son of the pregnant woman left behind. I have come to find my family'.

They gave him a young girl without brothers as a wife, and he brought her back to Ugri where his mother lived. He showed his wife to his mother and she was proud. They had children and their names were Maza, Dese, Yange, Gine and Tiburi.

He lived there, and when he died, was buried at Bullawe near the men's ceremonial ground. The sons scattered among the Masingle people.

The people on Yam Island thought of their relatives on the mainland. Saika was told that if he wanted to, he could travel back to the mainland. He came back to visit people and to travel around the land. When he came he brought fish from the reef, dugong, turtle, coneshells, bailer shells, shellfish, and trumpet shells. The villagers met him and he gave them these things from the reef. They brought him to the village, and he slept there. At that time they used counting sticks to tell the number of days. They gave him seven sticks, 


\section{FROM THE OTHER SIDE}

and told him to come back when the last one was thrown out. They held hands and took him to the canoe and gave him foods. They then said farewell. We now have relatives on Yam, Massig, Coconut, Boigu and now other islands as well.

This can be proved. The bones of the dugong, turtle and fish can be seen opposite the village near the creek behind the village of Masingara.

Rights to the use of Bine land by the Yam Islanders was also noted by Beaver ${ }^{31}$ although he failed to understand the history of Bine and Yam Island contacts.

Clan stories of the Agob speaking peoples who lived on the coast between the Pahoturi and the Mai Kussa naturally centre on contacts with nearby Torres Strait islands for, while the Agob people maintain close contacts with Boigu and Saibai islanders, the small size and isolation of their villages means that the economic basis of Agob life is generally underdeveloped.

Sigabaduru Village`

\section{Samoguad Clan Story \\ Told by Rubu Ag}

Agob Language

A man called Wagebau came from Saibai to Guiar (near the village between Sigabaduru and Buji). There he met with Pala, and Pala asked him, 'Why did you come here?' Wagebau said, 'I have some to visit friends'. Pala pulled a lump of grass and said if Wagebau killed the Guiar people, Pala would pay him with the woman Mogai from Guiar. There was a patch of jungle at Guiar and some of the young girls were living there. Their names were Basau, Abar, Podenen and Dauar. Wagebau went back to Saibai without a woman. He later heard that Pala had died. He returned to the coast on the canoe 'Melauar'. When he got to the village called Mogai, between Buji and Sigabaduru, he began to kill people. One man, Kua, the younger brother of Pala, survived and said to Wagebau, 'You have killed enough already - leave the rest alone'. As soon as he heard this Wagebau decided to make friends. Wagebau took some coconut leaf sticks and gave them to Kua, and told him that he should throw one out every day. 'When there are two left you will know I am returning from Saibai', he said. Wagebau returned to Saibai, and later came back to the mainland. The villagers covered themselves with mud, and took their bows and arrows to meet with Wagebau. Kua said to make friends and have a feast, so he took Wagebau to the place where they slept. Kua then got all the girls mentioned and dressed them all the same in grass skirts, and sat them before Wagebau, and told him that 'the girl in the middle will be your wife'. Wagebau took the girl and sat next to her during the feast and told Kua, 'I will be going back to Saibai tomorrow'. Wagebau sang this song:

'Koidirim mau rawai

Tari napa koidaudaia muyagar

Ah - oh - rawakutaiyanoue

Mapanaga uzu paganue.'

meaning

'Big Cassowary (the girl) is going to the place (Saibai) 


\section{ABORIGINAL HISTORY 1989 13:2}

When this man shook the Uzu tree, the seeds fell down

He got his prize and now he is going back.'

Wagebau then slept, he got Mogai and took the grass skirt off her, and hung it on a tree near the shore at Gulal-Gulag Toai (creek). As soon as he left this creek, he and Mogai sailed to Saibai. The people did not know where she was going as they did not know Saibai.

When Wagebau and Mogai settled on Saibai, they had children and some of the descendants are: Bamaga, a town on Cape York is named after him; Wagea, a former Council Chairman; Kala is living on Saibai. There are now many grandchildren.

Laade $^{32}$ emphasised that the strongest and most sustained contacts between the coastal Papuan peoples and the Torres Strait Islanders were centred on Mawatta. Laade and Beaver, ${ }^{33}$ both stated that the Kiwai speaking peoples at Mawatta acted as intermediaries in trade between the Torres Strait Islanders and the people living inland from the southwestern coast. This fails to account for a number of facts brought out in oral evidence. The 'bushpeople' established the earliest contacts emphasised by cross cultural marriage, adoption and trade. Oral evidence will show that it was after the establishment at Mawatta of the mission by the London Missionary Society in 1872, and the development of the commercial pearl shelling and bêche-de-mer fishing industries around the Warrior Reef, that the Kiwai managed to secure a more permanent place on the southwestern coast past the Oriomo River. The Kiwai were then able to move further along the coast to Mabudawan after the establishment of the administrative post in 1891.34

The story of early contacts between the people of Kulalae, along the Pahoturi River states:

Kulalae Village

Story of contact with Torres Strait Islanders

Told by Zate Nog

Our relationship with the Torres Strait Islanders began a long time ago, when we lived at Basirpuk (now called Mabudawan). The islanders saw us there. At that time we wore only our traditional clothing, we had no knives, plates and other things. Our only method of transport was bamboo rafts. The islanders, seeing our way of life gave us turik (iron, also knife), saucepans, etc. At that time our language was Saibalgan Yamukud (Saibai Island language). Today our language is similar to the Eastern Islands language. From that time, the islanders returned with gifts and our relationship grew stronger and stronger.

At that time, our method of fishing was the use of baskets, and the islanders taught us how to use fishing spears. The islanders told us to fish at Ait Reef. This area was free for all to use. From then some young men went to work for the islanders in order to strengthen our relationship and this practice still continues. Soon after we made contact with the islanders there 


\section{FROM THE OTHER SIDE}

was another migration of Kiwai people from the Fly River, and they pushed us back inland by tribal fighting, and now they live at Mabudawan.

Since the Kiwai came we have had trouble maintaining the relationship with the islanders which was really working. This has had some effect on the language for now we learn the Kiwai language. But it still did not completely stop our old relationship. Today we trade regularly, and some still know the language very well.

Intermarriages have taken place, and our men have married Torres Strait Islander girls. Today we have people from the village living over there, who have become Australian citizens, but they come back for holidays, especially at Christmas.

Somewhere between first contact and now, we were living about 20 minutes west of here at Togo, an islander named Tanu Nona from Badu came in a fleet of luggers to this place, Kulalae, and brought flour, turtles, kerosene, tin drums, rice, clothes, saucepans, etc. In return we gave them yams, mats, bananas, taro, etc. The name Kulalae, is a Torres Strait Islander name. Today, because of the restrictions, we do not see each other as much as we want to, but we do go to see them by getting permits from Customs.

Contacts between the Gizra speaking people and the Meriam speaking people were also established before the coming of the Kiwai.

\section{Kulalae Village Gizra Language \\ Story of Relations with Eastern Islands of the Torres Strait Told by Sair Buia}

Our people were going to Gida for initiation ceremonies on the land where we learnt our lore. During this time people used rafts to cross rivers and at this time the wind was blowing from the northwest and the current was very strong. On the raft were many people, including a pregnant woman named Agor. They could not cross the river, and began to be washed down the river. They had fruit and nuts from the bush, because this was the lean time for food, before full fruiting and before the good taro and bananas were ripe. The wind and current took them out into the sea and right over to Murray Island. Their fire went out while they were travelling. There were other people on Murray Island, and they asked these people: 'Where have you come from?'. The people told them that they were Gizra people. The pregnant woman gave birth there, and the raft people mixed and married into the Murray Island people. On Murray Island there were no breadfuit trees, or nuts, etc., but now these islands are full of fruit trees that the Gizra people took with them. Today there are similarities in the language, eg turik (iron), yao (come) etc.

Wurm ${ }^{35}$ noted this linguistic affiliation stating that not only was Gizra the closest linguistic relative of Meriam but that Meriam had also been heavily influenced by the southem Kiwai language.

Wurm 1975:349. 
ABORIGINAL HISTORY 1989 13:2

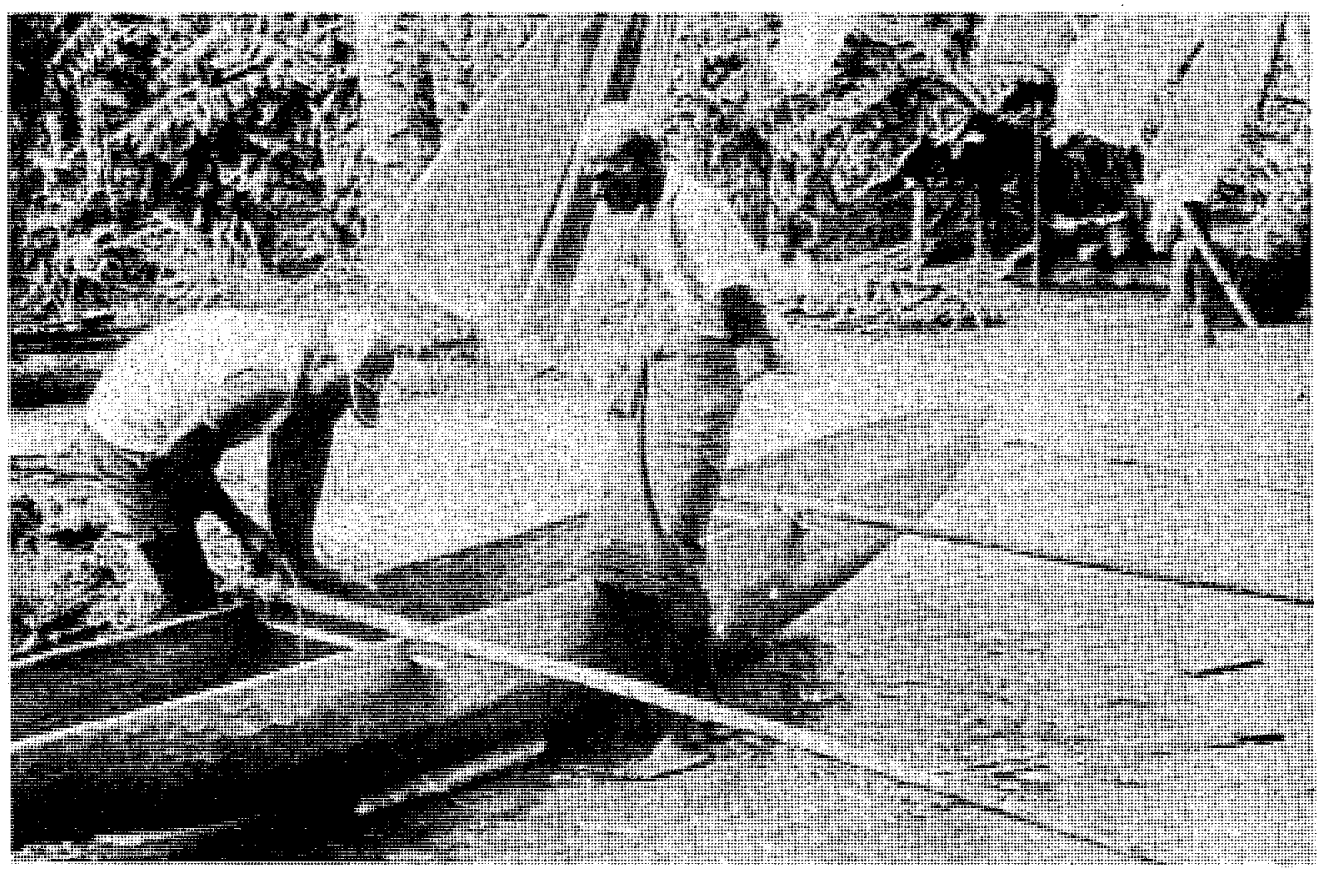

Above: Moses Somogi (left) repairing small canoe, Kadawa village.

Below: Kulalae village, Pahoturi village, showing large canoe (puputo) used for fishing and market trips, and for long distance voyages (See: stories by Zate Nog and Sair Buia)

[photographs by David Lawrence, 1986]

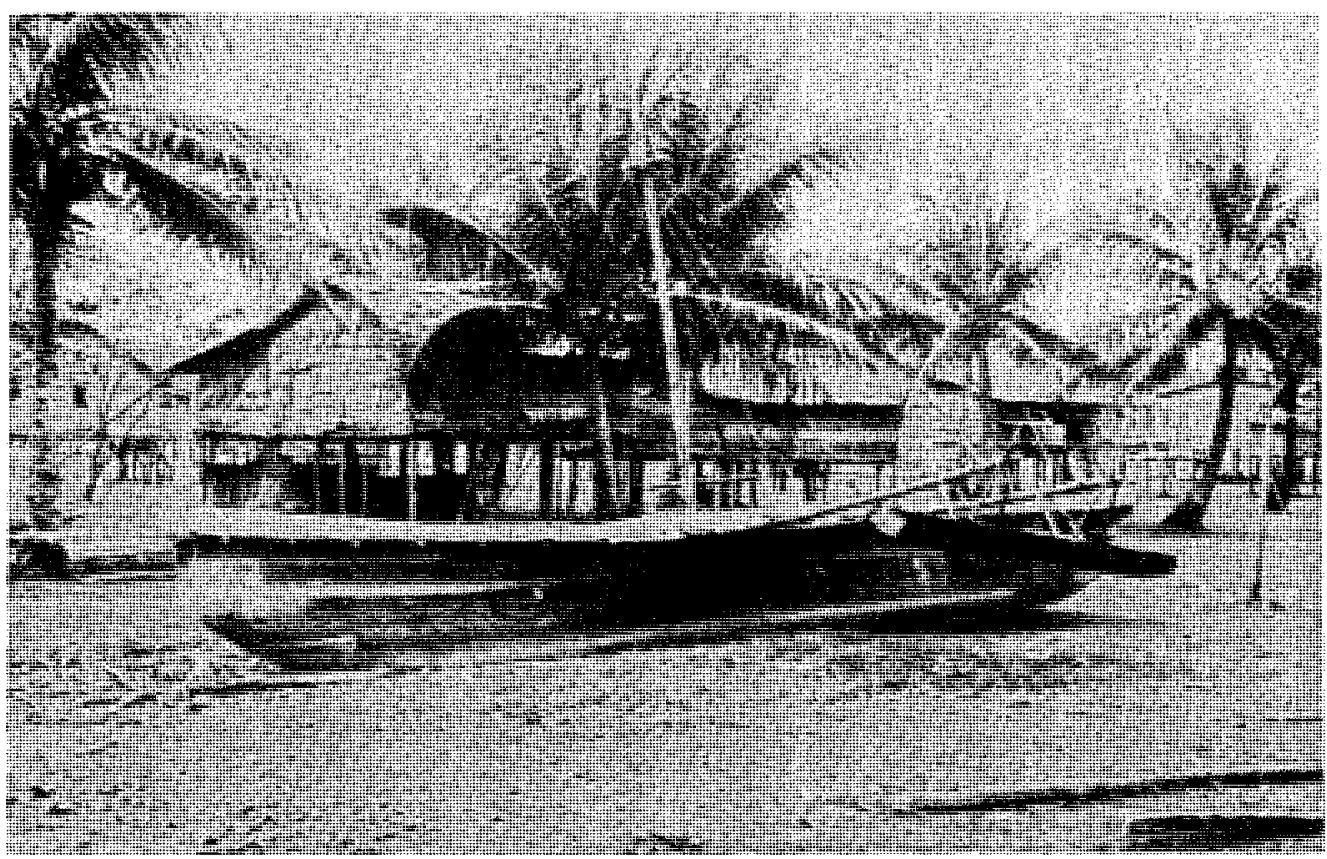




\section{FROM THE OTHER SIDE}

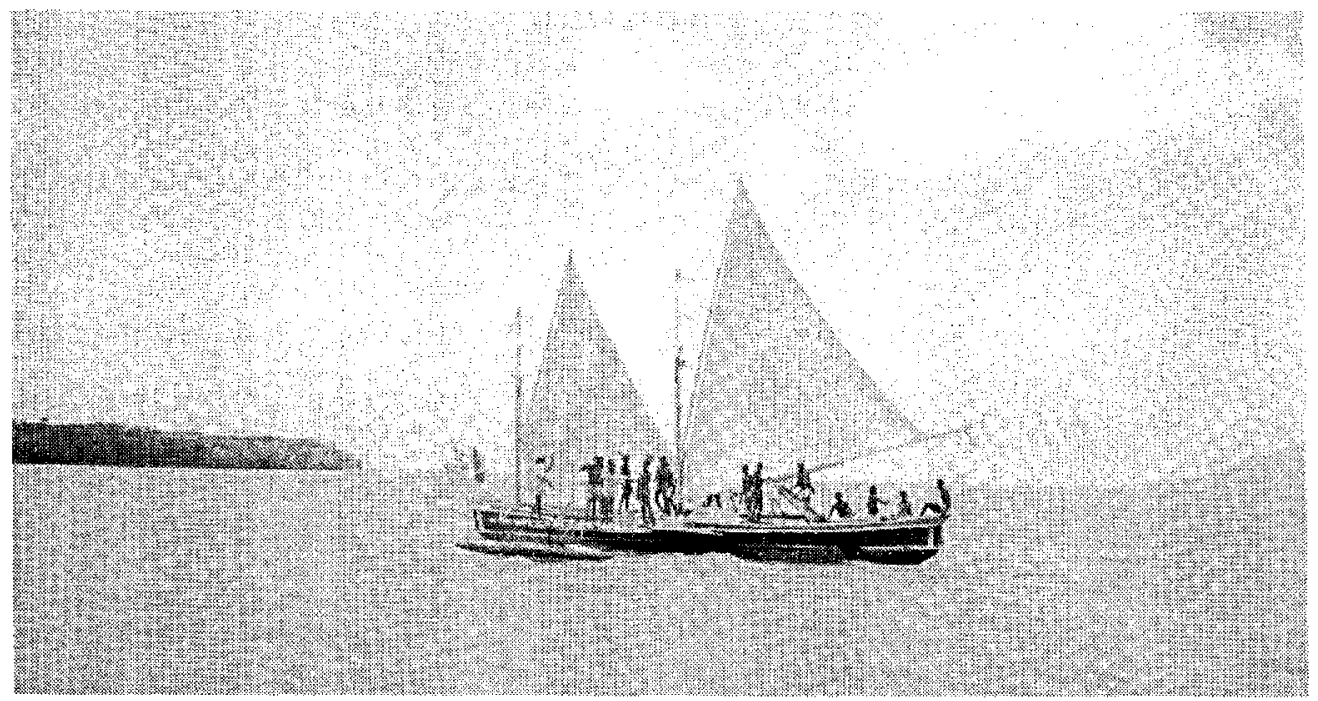

Canoe (motomoto) from Mabudawan village sailing to Saibai (left) and Dauan (right) before undertaking long distance fishing trip into Torres Strait (See: story by Jawagi Maru)

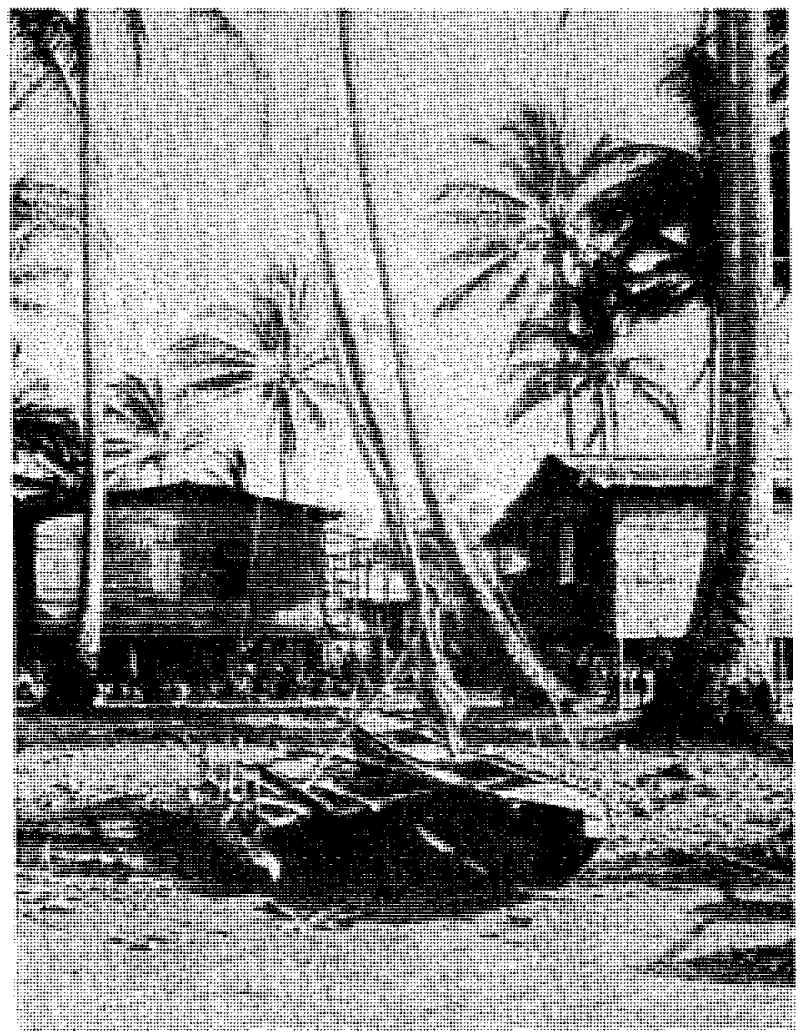

Kadawa village showing single-outrigger canoe (tataku) and typical coastal Kiwai houses. (See: story of Kadawa village by Moses Somogi) [photographs by David Lawrence, 1986] 
Landtman ${ }^{36}$ stated that the Kiwai speaking people at Mawatta maintained regular contact with the Torres Strait Islanders. Intermarriage, cross cultural adoption and regular trading expeditions served to strengthen kinship ties and facilitated the exchange of cultural practices.

It is the story of Bidedu and the establishment of contacts between the Kiwai speaking peoples from the Fly River and the peoples from the land along the southwestern coast that is crucial to an understanding of the linkages between the Papua New Guinea people and the Torres Strait Islanders.

The story of Bidedu was told by Jawagi Maru from Mabudawan village. It is long and complex and the first part is paraphrased here.

Bidedu lived originally in the bush near Kuru between the Oriomo and Binaturi Rivers. One day an eagle dropped a bone in his garden and Bidedu realised that although it was a fish bone it was unlike any that he had seen before. He resolved to travel to the coast and took with him his fighting weapons and seeds from his garden. He finally reached the shore opposite Daru Island and although he saw smoke rising from the trees on the island he could see no one. He heard sounds from inside a fig tree that was covered with vines and realised that people must be living inside the tree so he took one of his cassowary bone daggers and broke the vine. The people were released and Bidedu named them one by one making them his brothers and cousins. He showed them how to make fire, how to wash, how to cook, and he taught them the right foods, such as bananas and sago, for he had brought these things from Kuru. He taught them to plant foods and they established gardens at Dudupatu, near the mouth of the Oriomo River. It was Biza, the first man from out of the tree, that Bidedu instructed, by magic, in the ways of gardening, hunting and making bows and arrows. It was Biza who settled along the coast and named the area Mawotto-Dodomea meaning 'to cross over to a fine beach'. The people who came to the beach were the Kadawarubi (the Kadawa people).

These people crossed to Daru on rafts and there they met the Daruowera and the Hiamo peoples who instructed them in making canoes and hunting the dugong and turtle.

Generations passed and the people remained settled at the beach until Gamea grew to be a man, and it was Gamea who led the people along the coast in search of new land.

Mabudawan Village

Kiwai Language

South Coastal Kiwai Dialect

Story of how the Kiwai settled along the Coast

Told by Jawagi Maru

Gamea thought that he must build another house/village. Many children had been conceived from the one woman who had lived in the vine tree. So from there Gamea started down the coast looking for people. He started collecting people from Kiwai Island, Parama, Sui, etc., and some from this side down to Saibai and Boigu. As he was travelling the coast there was no fighting because he made magic while he was travelling. When he collected the people he took two other men named Kaiku and Parema from Daru and the village started to grow. Today that family is all here at this village called Unumere clan. They stayed a long time at Mawatto, and then moved to Gireturi (also called Neture), which is the bay at the point of Katatai, called Koipomuba (Sandbank Point). Bidedu moved to this side of Mawatto called 


\section{FROM THE OTHER SIDE}

Wiomuba (muba meaning sandbank), that is the point of the Oriomo River. He would look after the people there and after he would drink Otagamada (kava drink), and tell stories and listen to people talking to each other. They also started making gardens, but because there was no water, and many mosquitoes, they decided to move to a better place. Also there were many people there. Gamea took some men: Mabul, Gagare, Herepe, Maiope, and his son Wasomo, and joumeyed down the coast. Between Dauan and Boigu, near Buru Island, their canoe turned over and Wasomo drowned. Gamea journeyed a second time from Daru, taking Maru as his son from Daru. When they left Mawatto they came to Kaparo, a place near Oeabina, where there is a big tree. He found a good place there, and cleared the land and camped there. There was no-one there - not even a footprint - only a sandy beach. From Oeabina, he found the Binaturi River. As he travelled the coast he named the rivers and places: Binaturi, Kura, Ramezi Creek, Augaramuba, the point near Mabudawan, Gugihi Creek, Marukura Island, Paho Island, where the dead are buried, Pahoturi, Minimini Island. Gamea named them all. From Mabudawan he went to Saibai, Dauan and Boigu in the canoe with a pandanus leaf sail. He learnt to make this canoe from the Daru people.

On the second trip along the coast, Gamea put the canoe at Mabudawan. There was no fighting or cutting of heads, only peace and friendship. That is why the islanders are friends. When he went to Boigu other people started visiting the island then. For the second trip they got a canoe from Kiwai Island, and used a coconut leaf sail. When he went to Saibai and Boigu he found people there. Gamea was taken care of by the people of Boigu and one Saibai man went back to Mawatto.

Gamea invited this man Dagai from Saibai to teach his people in Mawatto how to make dugong harpoons, and how to hunt the dugong. Dagai started making spears to go fishing, and dugong platforms. Dagai said that he would tell his brother Wusuru from Boigu to come and help him make spears. Wusuru came from Boigu straight to Daru, and he and Gegera and Iwoimo made a house at Mawatto. They later moved to Binaturi, when Mawatto grew. There they married and the village grew. There was no Tureture village, all the people were Kadawarubi. From Binaturi they went to Oeabina. They made a small house there, but moved to Old Mawatto (real name Kadawa).

Where the houses are now was the garden place before. They stayed at the shore, but made good gardens. There were plenty of women at Kadawa, they married there. Each man had two wives, because there were few men. The first wife helped with fishing and gardening, the second wife only had the children. This was how they lived in the old times.

This state of intergroup conflict was noticed by Chester ${ }^{37}$ in 1870 . Discord between the Kadawarubi and the Tureturerubi was caused by the discovery of an abandoned illegitimate baby. The second part of this story documents the divisions within the community which caused the Tureturerubi to move away with their headman Kuke. 
One Tureture man speared a Kadawarubi man with an arrow. The man who was killed was called Garibu. This caused fighting between the people. The big men, Gamea and Kuke, tried to stop the fighting, but the young people wanted to separate. Now the Kadawarubi and the Tureturerubi live apart. First the Tureturerubi went to Yomuso, then to Kuokawa. Then they went to Doika. They wondered how they could make friends again. One woman was given by the Tureturerubi to the Kadawarubi to stop the fighting. They put their fighting equipment around her, and on a stick, called a Nunaota. She was dressed at Doika and taken to Binaturi. They planted the stick in the ground, and left the woman there. Women were exchanged in this way with other places such as Boigu, etc., in order to stop tribal fighting. This woman was given to the Mabudawan section of the village to make peace. Her name was Erema.

Bidedu had taken the seeds of plants to Tureture and he had spoilt the other gardens with his magic. Biza was not aware of this. The Kadawarubi did not harvest food for about three years. Samuki Gamea said that he would cross to Tureture and bring Bidedu back. Bidedu refused three times to return. He sent for one of his three sons. This son, Sobi, brought his magic basket, and Bidedu shared his magic. Bidedu told Samuki Gamea that he was to stay with him and be taught the garden magic. Bidedu asked where the gardens were placed and he was told at a place called Poponatatio. Bidedu's second son had burnt a garden place at Anaipodo. Bidedu had taught his sons the garden magic. Early in the morning Bidedu shouted to Biza that Samuki Gamea would look after the gardens. He also told Biza that Bidedu (the second son), Gagari, Herepe, Maburu and Maiope must also stay with Biza. The people took Bidedu's son to the village and made Otagamada for him. Bidedu's son stayed and they planted the gardens the next day. First they burnt the garden place, then they filled a bowl with seeds and covered them with water and then they scattered the seeds on the ground. The man making this magic was decorated with flowers. They are still using this garden place at Old Mawatto. Bidedu was left at Tureture.

The movement of the Kiwai down the Fly River and along the southwestern coast from established villages on Parama and then Katatai is evident from the oral history. The journey of Gamea and Kuke, estimated by Beaver ${ }^{38}$ to have occurred about 1800 , parallels the journeys of Sido, and it was through the Sido myth that the Kiwai made claim to the coastal lands, reefs and waters of the Torres Strait.

\begin{tabular}{cc} 
Kadawa Village & \multicolumn{1}{c}{ Kiwai Language } \\
East Coastal Kiwai Dialect \\
Story of Kadawa Village \\
Told by Moses Somogi
\end{tabular}

The people of Kiwai Island lived at Iasa. There were no people on the coast. When the Iasa people began moving some went to Manowete, the north bank of the Fly River. One old man named Sewota crossed from Iasa to the mainland on his canoe. He took his son with him but on the journey the fire

38 Beaver 1920:61. 
went out. At that time there was no Mibu Island. He came to past Sui on the coast. His son began to cry because he was hungry, so Sewota stopped and went looking for fire, but was unable to find it. He finally came to Gibu, a small creek north of Gewi. Here he left the canoe and went up this creek. He shouted but found nobody. He came out from the creek, found Gewi Creek and came to Hubo near Toro Passage, opposite Gaziro. His son was fainting from hunger. He left the canoe at Hubo, made a shelter and left his son there. He told the boy to stay there while he went looking for fire.

He came all the way from Hubo to the river named Urugowoturi near Old Katatai Point. He saw one man here who asked him: 'Who are you?' He replied: 'My name is Sewota and I am looking for fire'. The man told him to stay where he was and he would go and get fire for him and bring it back. This man's name was Bagari. Bagari got the fire stick, he threw it to Sewota from the other side of the river. Sewota ran after the fire stick and in doing so made a creek called Magumuba. Sewota got the fire, and made a fire for his son at his camp at Hubo. He fell asleep. Later, he wondered why Bagari did not want him to cross the river, so decided to look for his footprints and follow him into the bush.

While looking for Bagari's footprints he met another man named Biza at Wiomuba, the western side of Dorogori, and he made friends with Biza. He stayed at Biza's longhouse. He was told that there was one man on Daru Island named Damabe. While this Damabe was staying at Daru a man named Bani came from Boigu Island. Damabe told Bani that he could not stay on Daru, but that there was a man on Hubo and he could stay with him. This man was Sewota. Sewota told Bani that he was to go to a place called Doridori and to look after that place. He said to Bani: 'Here is my small son. Take him with you and teach him how to fight as I am getting too old.' So Bani took the boy and settled at Gibu but named it Daridari (dori in Kiwai is dari in Saibai language and means man's headdress).

People from different villages came to form two longhouses called Kudin and Wasigena at Arimaturi, near Gewi. While they were staying there they found a large sandbank was coming up at Parama. The people had seen the sandbank but they thought that it was a sea monster. When they sailed near there they stayed close to the mainland. Whenever they went close to the sandbank, the crashing waves frightened them and they would return to Wasigena. They decided to find out if it was a real monster so they went and planted a stick in the sand, they saw that it was land and called it Oweaparama (owea means found). They planted trees at Arimaturi. Some people left this old village and settled on Oweaparama. While they were living there conflict arose over relationships between men and women and the village decided to separate. They split in the middle and some people stayed at Parama, others went to Gaziro but there was no water there so they crossed over to the mainland and settled at Komako, also called Katatai. They made camp at Komako. One man called Bidedu came from Kuru and cut the vine tree. The Apuapu (vine) people came out. The Apuapu people went to Dawarima, then moved to Neturi and then came to Kadawa. Gamea and Kuke, two brothers, were from the Apuapu people. Kuke was the elder, Gamea the young": brother. Their mother at one time left Gamea on the beach and their father said: 'I have plenty of boy children.' So he gave his son Gamea to the 


\section{ABORIGINAL HISTORY 1989 13:2}

Mabudawan people. Gamea and Kuke later moved west and Kuke later moved to Tureture. One fellow named Sebea and his wife, Siworu came from Iasa. Sebea left his wife in the canoe. The village men said to him to come to the men's house. They gave him otagamada to drink and he went to sleep. While Sebea was sleeping all the village men went and took his wife and assaulted her. They started at night and continued until early moming. When Sebea woke in the morning he went to his wife and she told him of her ordeal. He took her and started back to Iasa. Sebea put a plack palm container under Siworu and when the container was full of fluids poured it over the side.

When he came to Wadaewi he cut cane there for bow strings and later took them to the people at Wasigena. He told them how the men had spoilt his wife. Sebea and his wife later arrived at Iasa, and told their story to the people. They all prepared their fighting gear. They came down from Iasa to Wasigena, and then to Kudin where they decided amongst themselves that Bani should lead the fight. Bani's magic was powerful and before leading the group he made magic and then they sailed down in their canoes. They came to Hubo and left their canoes there. The men told the boys to stay behind with the canoes while they moved to the village. They were told to move the canoes to the village when they saw the first birds flying in the morning. They were told that when they paddled past Gibea headland they were to burn coconut husks to create smoke that would attract attention. The men circled the village longhouse some from the beach and others from the bush. The men slept waiting for the daylight. At morning, the boys came along the coast. They lit their fires and one woman who was washing at the beach saw them and shouted to the Kadawarubi that the Iasa people were coming. When the men from the longhouse ran out to see the canoes, the men from Iasa encircled them. Fighting started. The Iasa men killed some Kadawarubi, but others ran away. Those who ran were the ancestors of the people who live at Tureture, and Mabudawan. After this fight Kuke and Gamea fled to the west. Gamea later returned to the village (to see if it was empty). He later went back.

When the Apuapu people came out of the vine tree, there were people living at Komako (old Katatai). To form Katatai the old man's greatgrandfather came from Iasa and to Hubo. The son of Sewota learnt to fight.

The present village of Katatai was formed by people from all parts - some Apuapu, some from Fly River islands, some from Torres Strait islands, such as Yam Island (Gaidiri, his son Damabe, his son Ausa, his son Daida Ausa), others from Boigu (Boigudai clan), one man from Murray Island (Naimaru), and one from Yorke Island (Warasi). They settled at Katatai, but some moved to Kadawa when water disturbed the village.

The Kiwai hold on land along the coast was only tentative, dependent upon permission by the 'inside people' to permit settlement. ${ }^{39}$ For this reason coastal Kiwai villages are situated on the narrow sandy foreshore, often backing on to river marshlands, or swamp.

In the oral evidence presented here the common theme is that contact between Islanders and Papuans was firmly established prior to sustained European contact in the Torres Strait region. A commonly held view, though now increasingly disputed, regarded Melanesian 
societies as relatively isolated, small, self-contained and static groups prior to European intervention in the late nineteenth century. The evidence presented in oral accounts disputes this assumption.

The lines of communication formed through marriage alliances, kinship ties and trade friendships were set in the period prior to European contact. European penetration into and across the Torres Strait and into mainland Papua New Guinea followed these customary lines of contact.

The stories and legends of Melanesian peoples form a framework of 'mythological topography' within which the movements of ancestor heroes, legendary warriors and, more recently, old men who have become renowned for their journeys, are incorporated. These oral accounts legitimise recent migration movements and serve to consolidate linkages between peoples. In the Torres Strait the disruption to these lines of communication caused by political divisions between Australia and Papua New Guinea has been particularly apparent.

Chester ${ }^{40}$ wrote an account of a trip to New Guinea accompanied by Captain Banner and two Tudu Islanders. Unable to ascertain their exact position due to flood tides and currents, they landed near a village of about 12 houses close to a small river (Binaturi). They later found that the village was called Katow (old name for Mawatta). Another village three miles to the north was Tureture. The villagers were at war with each other. Chester noted that they understood Kiwai.

Men from the Torres Strait pearling stations raided Papuan villages for food rather than obtaining food by fair trade. For example, Gill $^{41}$ reported that the eldest daughter of Sauai, headman of Dauan, was stolen by a party of pearl divers who also robbed the plantations in broad daylight. Chester visited Tudu in 1870 on his way to New Guinea and remarked that the island was inhabited by a camp, on the southeast side, of enough people to fill 18 canoes, which he later estimated at 43 men plus their families. Captain Banner had established a fishing station on the northwestern side in 1868 and employed about 70 South Sea Islanders, many of whom had intermarried with local women. Thus evidence for contacts between Europeans and Islanders predates the establishment of the mission at Mawatta in 1872.

Documentary evidence of contact between European traders and sailors in the Torres Strait and the peoples of the southwestem coast of Papua is found in accounts by missionaries and government officials during the early period of contact, particularly after 1870. Early contact history, that is, the history of European contact in Papua can only be described in terms of the establishment and decline of missions and the rather reluctant growth of colonial administration in the Fly River/Torres Strait area. Annexation of Papua was in fact announced by Commodore Erskine of the Royal Navy, Australia Station, from the verandah of the London Missionary Society mission house in Port Moresby in 1884 . The two partners, mission and government, were forever, if unhappily, interwoven in the development of a European Papua.

The first European to settle in Papua was the Reverend W.G. Lawes of the New Guinea Mission of the London Missionary Society, in 1874. In 1871, the Reverend Samuel Macfarlane and the Reverend A.W. Murray had founded a mission on Darnley Island and posts on Dauan and Saibai Islands in the Torres Strait and, in 1872, Samoan teachers were landed at Katau (Mawatta) 48 kilometres east of Darnley Island. By 1900, the Fly River area 
was subject to considerable mission activity, mainly from South Sea Islander pastors and teachers.

The impact of explorers, prospectors and traders, and especially the uncontrolled labour recruitment in the late 19th century, on village life in New Guinea, was a fundamental reason for the extension of colonial administration over Papua and the Torres Strait islands

The following is an oral account of the impact of these first meetings upon the people of the Binaturi River and the subsequent introduction of European tradestore goods obtained, not by customary exchange, but by wage labour.

Masingara Village

Story of first contact with men from Somerset

Told by Pomame Buje (Buie), Ibaji and Gadua

The name of the old village was Masingle. The people brought this name with them on their journey. There were four men's houses in the old village. They were: Magamaer (mother of the men's houses); Palemete (red skinned tree men's house); Dibepupu (resting place men's house), and Norawale (red flower men's house). A man, Yange from Damlearme subclan, got married to a woman called Gibua. As he had no land nearby in which to plant banana suckers, Gibua brought him to her clan's land to plant his garden. During the day they would work there at a place called Palegide. One day he decided to go fishing at the junction of the Bullawe and Binaturi Rivers. In those days, when they went fishing, they used fishing line made from coconut husk fibres, hooks made from lawyer cane thoms, and the sinker made from a ball of strong clay. Yange caught some fish including one eel. While fishing, Yange fell asleep against a tree leaning over the river. Suddenly he heard a noise and saw a European boat in the river. He tried to escape but could not, so he tried to hide. The boat came close to him and he heard one man call out 'I see you. Don't hide'. The men on the boat caught him. Yange was frightened and shivering because he thought they were going to kill him. The European man also took the fish, the eel and Yange's bow and arrow. The boat continued up the river in search of other people, but at Iremisiu a tree had fallen across the river blocking it. While the boat crew were trying to clear the tree, the people of Iremisiu attacked the boat. The men on the boat fired their guns at the villagers who ran away. The boat then turned around and sailed down the river. They sailed to Somerset. Yange's wife, brother-in-law and father-in-law searched for him and, believing that he must have been taken by a crocodile, sent a message from Bullawe village to Masingle village. Yange's wife dressed in widow's mourning clothes. Because they had no body to bury they dug a grave and placed a trunk of a banana tree, called Edetane-Doba, in the hole and covered this with dirt. They then held a funeral feast for him.

Meanwhile, Yange was living at Somerset. The Europeans taught him how to cook rice, how to make damper, tea, boil hot-water, eat sugar, etc. He was also taught how to wash calico (clothes), use soap, and how to use towels. They taught him how to use razor blades, glass mirrors, combs, knives, etc. He remained there for a while, some say two to three months. Later they brought him back by boat. They anchored at the mouth of the Binaturi, there 
was no village at Mawatta, and they unloaded all his things, put them on the beach and covered them. In those days the river was only a creek. They gave Yange a set of counting sticks and told him that they would come back at a future date. Yange walked up the road to Masingle and the boat returned to Somerset. The road to Masingle was called Masingle-Gabe and went through the present village site. At Ugular Creek, Yange was seen by some village people, and they thought it was Yange's spirit returning because he was dressed in shirt, trousers and hat. For this reason European clothes were called abletuglu, meaning spirit's skin, that is, the clothing is hiding the spirit. Frightened, the people ran away. Yange started called out: 'I am not a spirit, I am not dead, I am alive'. The people heard him and turned around and started walking towards him. They then shook hands with him. They went with him to the Noawale men's house. The relatives of Yange gave him food to eat. They then went to Yange's men's house, Dibepupu. When the message went about that Yange had returned, the people spread mats on the black palm floors and Yange started to tell his story.

He told them that the Europeans who brought him back were turibiname (friendly people). After telling his story, he said that all the goods brought were still at the mouth of the Binaturi so they went to collect the stores and brought them back to the men's house, where the people gathered around. Yange showed them how to cook using saucepans. He served rice to the people on plates which he had brought. He also served rice in coconut shells, called wate. He opened tinned fish and mixed the rice and fish. He then showed them how to eat using spoons. Some used spoons made from shells called hinerore and geserore. The people tasted the food and saw that it was good. Yange explained all the European foods such as flour, baking powder, tea, etc. He showed them how to mix tea, wash clothes and bodies, how to use knives, axes, matches, black tobacco (they used to smoke iasuguba, native tobacco). Some women thought that soap was for eating but Yange told them it was only for washing. He showed them how to dress in European clothes. He shared everything among the village people but some people missed out. Yange told them not to worry as the boat was returning and they would be given stores then. He showed them the counting sticks and on the appointed time the boat returned from Somerset. This was the second trip.

Yange showed the people the boat. On the boat were also some fowls. Yange explained these birds to them and the children learnt to make the noise: 'oh - ga - oh - i - we - a - i - we - a'. The Europeans told Yange to unload the boat. The sailors went with the people to Masingle village where they shook hands with the village people. They shared stores with the people who had missed out in the first place. The boat then left Masingle and returned to Somerset. Yange remained behind. The Europeans then told the mission at Somerset of this place and the missionaries made a trip with the pastor from Murray Island called Enoka. This man's name was Enoch. The missionary made a settlement near the Noawale men's house. This place was called Aipupu (a type of tree called oni or wongai), because the pastor worked there for some years. Masingle people and Irupe people were still fighting wars but the pastor called the government to come and make a stop to the wars. William Macgregor took some police and came. He brought trade goods and went up to Irupe with some Masingle people. While he was trying to make 
peace the Irupe shot one Kiwai man named Dabu, whose family are now in Mabudawan. They speared him. The police shot some men, the European shot one man. They then left.

Masingle and Irupe people became friends after this. The pastor remained in the village and some people went to Somerset where they worked as labourers.

They then went to work for the government at Malukuwa (also Marukara) Island off Mabudawan. These workers planted coconuts and mangoes at Malukuwa. (These trees are still there). After this the Kiwai people travelled along the coast and settled at Mawatta after the missionaries. This was when Gamea and Kuke came to Mawatta. There was no Kiwai village at Mawatta before the missionaries.

Because there was not enough land and no sea passage at Malukuwa and Mabudawan, the government went to Yaru (Daru).

There the government settled for good.

Following the establishment of the colonial government outpost at Somerset in 1864, European contact with Torres Strait Islanders, and later with coastal Papuan groups, increased.

When the pastor left, some people moved to Bullawe with Muge, others went to Sair, others to Gugumete and to Biabu. From there the government came again and told the people that they were one people and should make one village, so they moved to the old village site near the graveyard. The Europeans changed the name from Masingle to Masingara. At this village the government brought the Union Jack and George (?) Murray came from Port Moresby and gave the people the King's head (photograph). From there the government and pastors continued to come until now.

'I see you'. The family of Yange still use this name, now spelt Seeyou, formerly Siu.

The skirmish between the Irupe people and the police under the authority of Macgregor occurred in 1891. It was also in 1891 that the first colonial administrative post was established near Mabudawan. ${ }^{42,43}$ Thus according to the Masingara people, the permanent settlement of the Kiwai on the southwestern coast occurred after the establishment of the mission.

The unscrupulous methods of obtaining labour in the Torres Strait region were graphically illustrated by Cannon ${ }^{44}$ who described how:

Old Edwards of the 'Blue Bell' used to relate with 'gusto' how he inveigled the men on board, got them down below, then made sail and cut their canoes adrift. They were taken for three or four years, then given a few old muskets, beads, whiskey, tobacco, or cloth, and landed at least anywhere, often amidst their deadliest enemies.

42 British New Guinea. Annual report of 1892:47, and

43 Beaver 1920:79-80.

44 Cannon 1885:30. 


\section{FROM THE OTHER SIDE}

Landtman ${ }^{45}$ also recorded stories of first contacts between 'white' men and Papuans. The coming of D'Albertis and the flag is still told although the story the author collected is very disjointed.

The opening of the interior and the pacification brought by colonial administration permitted the peaceful movement of the 'bush people' to the coast and eventually into the plantation labour force. It also enabled the Kiwai people to move further along the coast and establish a village at Mabudawan. The impact of European ways profoundly altered customary life in the isolated coastal villages of the Western Province from the early 1870 s.

Wim Village

\section{Story of the first lap-lap (European clothing) \\ Told by Abiam Mergor}

Before, in the old days, our great-grandparents did not wear lap-laps. It was during the lifetime of our grandfathers that the people saw their first lap-lap. Lap-laps were first used at Old Mawatta (Binaturi River), and slowly they moved by trade to Masingara, to Glulu, to Sogare, and to Podare. Our parents would go to Podare and get clothing there. At first, the people did not know what the lap-lap was used for. In those days, they did not get many clothes. Once they received the first lap-lap, they tore it into bits and used it to cover their private parts. At first they did not even know that clothing was to be worn. When we were children we started wearing European clothes all the time. In those days, people did not go to far away places. Clothing now comes from shops and friends. They cannot make this type of clothing themselves. It has to come from other countries like Australia.

The first missionaries to the upper Binaturi River area brought more than the Christian religion. They introduced tradestore goods and established new routes for trading from the isolated inland areas southward to the Torres Strait.

\section{Wipim Village}

\section{Story of Wipim Village and trading}

Gidra Language

Told by Sarawa Jugu, Mundar Kaus, Sagere Kaus, Bisai Saur and Birige Kugei

When the old people lived they did not have clothes or anything. The men were naked, the women had grass skirts to cover themselves. Before they had European tools, they used sharpened bamboo sticks to dig gardens, remove the grass and make drains. Before they had coconut scrapers they used shells. They also used these shells to make gardens by cutting the small sticks and grass to clear the land. Shells were also used to scrape the taro and vegetables. They were also used to make bows and arrows. Shells were the main object used. For cutting sago palm they used stone axes. Shells came from the Pahoturi and were traded with sago.

They do not know where the stone axes came from, perhaps they were just found and someone made them. Axe handles were made from a hard tree. Before it was fitted they made a hole in the wood with fire, then they used cane

Landtman 1917:538-541. 
to fit it to the wood. It would take all one day to cut down one sago palm tree. There were few axes, sometimes only one in the whole village. The axes were not sharp, and sometimes the force of the blunt axe on the sago could force a man backwards. This all happened before the trade in (metal) axes. This is how the old people lived.

Clothing was brought by one of the Europeans. He brought clothes and the Bible. His name was Sare. He came up from the village of Kadawa (now Mawatta on the Binaturi). When he arrived at Kadawa village, because it was the first time that they had seen a European, they were all frightened and ran away. When he found that everyone had run away, he went away but later came back. Before he came again he loaded a boat with all European things, like rice, sugar, clothes, tobacco, pots, saucepans. When the time came he started up on the journey from the coast. As he came closer to the village, people saw the boat and thought it was a very big wild pig coming on the sea, because they had not seen a boat before. Some felt very frightened and took off again into the bush, but others stayed and watched. It came from Thursday Island way to Kadawa.

The man named Mr Sare (Murray) came from the boat and called the men in the village. He told them to unload the boat and take goods into the village. The men shouted to those who had run away, to come and help unload the boat. They took all the goods to the village. The first thing he had was tobacco - he got the cigarettes and matches and lit it and puffed it first. He told them it was not food. He gave it to the village people. After that he taught them how to cook rice in a pot with water. He got a plate and served out the cooked rice. He opened a tin of meat and put it on the rice and showed the people how to eat it. Afterwards, they ate together. After this he showed them how to cook flour, biscuits, and other things. He showed them the foods for eating, and drinks for drinking, such as tea, lolly water and other things. $\mathrm{He}$ showed them black tobacco.

After teaching them these things he got a roll of material and cut it and gave the cloth among the people. He told them that the cloth was for them to use to cover their bodies. At Kadawa he told them that he was taking one of these rolls of material inland. Mr Sare asked if there were other villages inland because he wanted to see them. They went up the river to Glulu village with a man named Musi. Mr Sare told Musi: 'Here is a roll of material. You will take it to the other villages'. Musi went to Podare and gave it to them there. Mr Sare and the Kadawa men went back to Kadawa.

Musi spent some days at the village at Glulu. He sent messages to the men at Podare for all the men to visit him. He told them that he was bringing the skin of a dead man. He told them to made a welcome for him at Podare. He said: 'When I arrive, I will bring this skin, and you should hold it and smell it with your nose'. After sending this message he went out and later arrived at Podare village. They made a welcome, and Musi put the cloth down and told them to touch and smell the cloth. He called it kobargum or the skin of a dead man. Next day, Musi cut the material into pieces and gave a piece to each clan. This was the first time to see clothing in the Podare area. He showed them how to wear clothing. Musi returned to Glulu. He told them that Mr Sare would come and they should select some men to become the mamoose or police constable, deacons, pastors, and other things. The headman was to be 


\section{FROM THE OTHER SIDE}

called mopiam. Deacons were called dekuna. Pastors were called missionaries in those days. When Musi left, Mr Sare came and he was the first man to bring the Bible. He brought a gun with bullets and shot the branch off a big tree. Some people felt very frightened but he told them it was only used for shooting animals, and showed them how to do it.

For trading, they took a walk from Wipim to the villages near the coast. They traded with grass skirts, headdresses made from cassowary feathers, bows and arrows, drums, and native tobacco. The two villages that they traded with, first was Kadawa at Binaturi, and then with Masingara. For these things they gave them matches, clothes, knives, axes, and hoes to make the gardens.

Nowadays they still trade this way, but also go down to Daru now.

After Mr Sare went back they went to work for the Europeans at Port Moresby. Some of these men's fathers were the first to go to work for the whites.

When they got their jobs they learnt to speak English and how to cook food, cut grass, mix cement and work as washbois.

One thing like money was called apogran. This was like a big kina coin and very heavy. Goods cost one shilling. They could buy from both sides of this coin. They bought things from the boss. They did not have any education.

The establishment of colonial administration in Papua New Guinea and the internal colonialism' of the Queensland and Australian governments in the Torres Strait became the main regulators of the customary ways of the Torres Strait peoples. One of the earliest moves by the colonial authorities was the suppression of the headhunting raids of the Tugeri people from the Morehead River region. Raids by the Tugeri were a constant feature of life in the later part of the nineteenth century but it was the death of a European trader that brought police action and the establishment of a coastal station first at Mabudawan in $1890 / 1$ and then later at Daru in 1893. The story of the defeat of the war leader, Para, is still told. Para's death song is also sung, in Tugeri language, at the Kiwai speaking village of Mawatta.

\section{Conclusion}

Oral history concerns the relationship of written records to spoken tradition. 46 The role of oral traditions, within anthropological research, is their use as primary historical records. Collections of myths and legends, songs and chants do not themselves explain cultural history. They need to be interpreted and for this the essential task is to find the right informants versed in local traditions who can act as witnesses to events, thus enabling oral traditions to be assessed as historical records. In a changing society, oral traditions link people to their ancestors and events in the past. The sharing of recent events and experiences from the colonial past serves to orientate a people facing complex social changes towards a common future.

The sense of pride in the past is keenly felt by the people of the Torres Strait and Fly estuary region. However, the dissemination of the collected material is essential in maintaining the enthusiasm for the communal historic past.

Like a living society, tradition constantly changes. For this reason some ethnologists and historians are suspicious of oral history. No two accounts of the one event can be the same. One person's interpretation can distort historical fact. Stories passed by oral

46 Ruhan 1981:39. 
transmission are subtly changed according to present needs and present communal interests and the recorder can often be seen as an agent for the dissemination of local feelings and grievances. Warfare, disease and sorcery can be eliminated or glorified as occasion demands. If oral traditions can strengthen group solidarity 47 they can also be used to present a common front in the face of perceived external threats for they can be perceived as means for adaptation and accommodation. 48

Oral history serves to link people to their important cultural ancestors and to the events of the past which are the possession of the people as a whole or may belong to one clan or group in the society. Oral history is also a record of shared experiences, most particularly the experiences of migration, labour movements, intergroup conflicts, and the impact of the colonial period. These experiences may also be shared with other villages and language groups.

The stories presented here link the Islanders and coastal Papuan peoples to a shared common heritage. Oral evidence states that contacts were established and maintained well before the arrival of the first European traders and missionaries. It was, however, the arrival of the missions and the subsequent establishment of colonial administration that allowed for sustained and peaceful movements of peoples along the coast and into the rich fishing grounds of the northern Torres Strait.

Wage labour became the most important economic resource of the poor, isolated villages from the Fly River to Mai Kussa, and Papuans were employed under contract in the pearling, trochus and bêche-de-mer industries, and later, after the growth of the plantations, the Fly River men moved to other areas of Papua New Guinea as labourers.

The Torres Strait islands, especially Thursday Island, became an important source of desired European goods and many of the items of daily life, such as clothing, cooking utensils and food stuffs, entered the southern villages via the Torres Strait.

It is for this reason that the recently signed Torres Strait Treaty between Australia and Papua New Guinea recognises the common importance of 'traditional' economic activities between the people of the Torres Strait and the adjacent coastal area of Papua New Guinea.

\section{BIBLIOGRAPHY}

Beardmore, Edward. The natives of Mowat, Daudai, New Guinea'. Royal Anthropological Institute of Great Britain and Ireland. Journal 19, 1890:459-466.

Beaver, Wilfred N. Unexplored New Guinea. London, 1920.

Beckett, Jeremy. 'Whatever happened to the German Wislin?' In D.E. Barwick, J. Beckett and M. Reay, eds., Metaphors of interpretation. Canberra, 1985:53-73.

British New Guinea. Annual reports of 1889,1890 and 1892. Brisbane.

Cannon, R. Savage scenes from Australia. Valparaiso, 1885.

Chester, H.M. Account of a visit to Warrior Island . . . 1870. (Queensland State Archives. COL/A 151 Letter no. 3425 of 1870).

Gammage, Bill. 'Oral and written sources'. In Donald Denoon and Roderic Lacey, eds. Oral traditions in Melanesia. Port Moresby, 1981:115-122.

Gill, W.W. Life in the Southern Isles. London. 1876. 


\section{FROM THE OTHER SIDE}

Haddon, Alfred C. Reports of the Cambridge Anthropological Expedition to Torres Straits. [Vol.I, 1935: Vol.II, 1901-3: Vol.III, 1907: Vol.IV, 1912: Vol.V, 1904: Vol.VI, 1908.] Cambridge, 1901-1935.

The cult of Waiet in the Murray Islands, Torres Strait'. Memoirs of the Queensland Museum. 9(2), 1928:127-135.

Harris, David R. 'Foragers and farmers in the Western Torres Strait Islands'. In P.C. Burham and R.F. Ellen, eds. Social and ecological systems. London, 1979:75-109.

'Subsistence strategies across Torres Strait'. In J. Allen, J. Golson and R. Jones, eds. Dunda and Sahul. New York, 1977:421-463.

Laade, Wolfgang. 'Further material on Kuaim, legendary hero of Mabuiag, Torres Strait Islands'. Ethnos. 36, 1967:70-96.

'Notes on the clans, economy, trade and traditional law of the Murray Islanders, Torres Straits'. Journal de la Sociétés Océanistes. 29(30), 1973:151-167.

Oral traditions and written documents on the history and ethnography of the Northern Torres Strait Islands, Saibai - Dauan - Boigu. Vol.1 Adi - Myths, Legends, Fairy Tales. Weisbaden, 1971.

'The Torres Strait Islanders own traditions about their origins'. Ethnos. 33, 1968:141158.

Lacey, Roderic. 'Oral sources and the unwritten history of Papua New Guinea.' In Donald Denoon and Roderic Lacey, eds. Oral traditions in Melanesia. Port Moresby, 1981:252268.

'Journeys and transformations: the process of innovation in Papua New Guinea.' Pacific Viewpoint. 26(1), 1985:81-105.

Landtman, Gunnar. The folk-tales of the Kiwai Papuans. Helsingfors, 1917. (Acta Societatis Scientiarum Fennicae, XLVII).

The Kiwai Papuans of British New Guinea. London, 1927.

Lawrie, Margaret. Myths and legends of Torres Strait. St Lucia, 1970.

Ruhan, Anthony. 'Preserving traditions or embalming them? Oral traditions, wisdom and commitment.' In Donald Denoon and Roderic Lacey, eds. Oral traditions in Melanesia. Port Moresby, 1981:31-44.

Wurm, S.A. 'Torres Strait - a linguistic barrier?. In D. Walker, ed. Bridge and Barrier/; the natural and cultural history of Torres Strait. Canberra, 1972: 345-366.

ed. Papuan languages and the New Guinea linguistic scene. Canberra, 1975. (Pacific Linguistics, Series C - No.38).

Wurm, S.A. and Hattori, Shire. Language atlas of the Pacific area. Canberra, 1981. (Part 1: New Guinea area, Oceania, Australia). 